\title{
Ethnic and Social Determinants of East-West Migratory Trends in the Baltic Sea Area Transition Economies
}

\author{
J. ILARI KARPPI \\ Research Director \\ Department of Regional Studies \\ and Environmental Policy \\ University of Tampere \\ Tampere, Finland
}

\section{HEIKKI RANTALA}

\author{
Research Associate \\ Department of Regional Studies \\ and Environmental Policy \\ University of Tampere \\ Tampere, Finland
}

\begin{abstract}
The article concentrates on social and ethnic background factors in the Baltic Sea area transition economies with special reference to Estonian-Russian relations in Estonia. The general framework of the study deals with the transition to a market economy and the effects this transition has on east-west migration. The data for the study was collected in 1996 from four major city regions in four transition countries, this article being based on findings from Tallinn and St. Petersburg. A specific aspect discussed here is the connection between ethnically-based relative deprivation and willingness to emigrate. Indeed, the Tallinn Russians with the most notable tendency towards deprivation do indicate the highest propensity to emigrate. However, as remarked in the final section, the connections between the willingness to emigrate and factors underlying it are far more complex.
\end{abstract}

Keywords: international labor force mobility, ethnic segregation, relative deprivation, Tallinn, St. Petersburg

\section{The scope of the study}

In July 1997 the EC Commission outlined the future expansion of the European Union by publishing a document known as Agenda 2000. In this document Estonia, together with the Czech Republic, Hungary, Poland, and Slovenia was included in the group of the first five European transition economies to start the process aiming at future full EU membership. This expansion will open the European labor markets to new nationalities, still separated from the present EU area by a substantial gap in living conditions. Such gaps, resulting from differences in issues ranging from factors of production to income levels and purchasing preferences, are 
now widely discussed by both academics and practitioners, especially in Europe and North America. In a more generalized form they are referred at as asymmetries (cf. Clement 1997).

The European political and economic integration process has many dimensions. Membership is sought by the five transition economies, presumably the first ones to join the EU structures, in order to gain economic stability as well as military security, which would balance their reduced political sovereignty. However, EU integration is not just an economic or security arrangement. It goes far beyond a customs union or a common market. If we disregard the trade and tariff policy, its foreign policy instruments towards third countries are, moreover, designed to enhance cross-border co-operation. The Fortress Europe concept with strict outer borders surrounding the Union reflects largely the interests of individual member countries and their perceived needs to protect their labor markets from external migration pressures. The economic downturn of the 1990s has given rise to this school of thoughts.

The political side of integration has, however, highlighted a problem which would hardly matter in a common market setting. The question of ethnic relations in Estonia, especially the treatment of the country's Russian minority, 29 percent of the population in 1995 (ESA 1996, 55), has been pointed out as an issue that must be agreed upon by Estonia and Russia together. As a political union, the EU does not want to include within its territory a member with unsettled disputes with a major neighboring power. While emphasizing ethnic relations we assume that the de facto more difficult international legal problem, that of defining the physical border between Estonia and Russia - the future EU-Russian border - can be solved.

The scope of this study emphasizes the human aspects of integration and transition. We will concentrate especially on the ethnic relations involved in the process. After the Second World War economic cooperation in the West, the socialist community in the East and the global power balance placed ethnicity-related problems and questions in a minor political role. Hostilities were muted, but they surfaced again with the new nationalistic regimes in post-Cold War Europe and due to ethnicity-based problems. The end of the $1980 \mathrm{~s}$ and the beginning of the 1990 s saw the rebirth of nation states in the Baltic region. Simultaneously, the question of the legal status and future of the new, mainly Russian, minorities in the former Soviet Republics became a major challenge for the new democracies.

Our assumption is that the propensity to emigrate reflects not only increasing cross-border contacts and liberated human mobility, but domestic ethnic conflicts as well. However, migration is seen here in quite a traditional light, as a mechanism for adjusting the equilibrium between the supply and demand of the labor force. Cross-border income differences are thus seen as a factor that gradually causes the entire equilibrium to shift. Due to the increasing mobility of production factors, such as the labor force and investments, the overall wage levels can be expected to rise in the transition economies. In the Western market economies they in turn will rise much more moderately - if not decrease - than they would without the new supply of excess labor (cf. Cohen 1988). Whereas direct investments to the transition economies can be seen as a part of the restructuring of the Western production systems, labor force migration from East to West may intensify competition for Western job opportunities.

In these circumstances the questions of who migrates and in which direction become extremely important. In this respect also the abilities and propensities of different ethnic groups to emigrate are vital issues. We start the discussion with an overview of ethnic relations in Estonia in the 20th century. Ethnic Russians in the Tallinn labor market are then studied in the context of relative deprivation (cf. Runciman 1966) by interpreting the Estonians in Tallinn as well as the ethnic Russians in St. Petersburg as their reference groups. We continue by analyzing the propensity to emigrate in these three populations. Finally we discuss some implications the current findings may have on Finland and the research on transition economies.

\section{Historical perspective to the ethnic relations of Estonians and Russians in Estonia}

When Estonia in 1918 declared herself an independent state for the first time in her history, the share of Russians and other Slavic nations in Estonia did not exceed 8.5 percent. Russian 
settlement was concentrated in the so-called Transnarva region and in the district of Petseri, which was annexed to Estonia by the Tartu Peace Treaty with Soviet Russia in 1920 . Besides these eastern parts of Estonia, a small number of Russians had settled in the Estonian cities. The share of Russians did not change very much until the end of independent Estonia in 1940, when Soviet troops occupied the country. The first Estonian Constitution, dating from 1920, contained legal principles guaranteeing the existence of ethnic groups (national minorities) in the territory of Estonia. Estonian citizens of German, Russian, and Swedish origin were afforded the right to address state authorities in their own national languages. The law on public elementary schools in 1920 and the law on secondary schools in 1922 introduced elementary and secondary school instruction provided in the mother tongue. In 1925 the Estonian law on the cultural self-government of national minorities was enacted. Cultural autonomy granted to the minorities was a unique phenomenon in Europe during that time. Between the two world wars, the Estonian Republic actually was the only country which adopted and developed the idea of the cultural autonomy of national minorities (Geistlinger 1995, 94-95; Kirch 1995, 11).

The incorporation of Estonia into the Soviet Union led to a series of reductions in the territory of the Estonian Soviet Socialist Republic (ESSR), compared to that of the former independent Republic of Estonia. In 1934, a population of 1,057,500 inhabitants lived in Estonia, excluding the areas later to be incorporated into Soviet Russia. This population included 977,200 Estonians and 41,700 Russians. This means that in 1934 Estonians made up 92.4 percent and Russians 3.9 percent of the population in the territory corresponding to today's Estonia (Geistlinger 1995, 95-96).

Under Soviet rule Estonia, like the other Baltic republics, suffered heavily from deportations of her native population. In turn, Russians and other nationalities moved in. Population turnover was heavy: according to Runblom et al. $(1991,23)$ about ten million people lived in Estonia during the post-war era. When analyzing Estonians as a majority and Russians as a minority in Estonia, we are dealing with two very different cultural blocks. The comparison of Estonians and Russians is an analysis of two different mentalities. According to Kirch $(1995,18)$, the selfvaluation of Estonians represents to a great extent what they have managed to preserve as a heritage of democracy, independence, and Western values, although the West European social institutions, such as private ownership, as well as political and cultural voluntary associations based on personal freedom, were wiped out by the Soviet occupation in 1940. On the other hand, the Russians in Estonia came to a large extent to represent the overall image of homo sovieticus.

The non-Estonian newcomers who settled in Estonia since 1945 came from different geographical areas and national cultures. Moreover, their image of society differed from the Estonian West European traditions. Their relatively closed communities were to be found in several industrial towns but not in the countryside. They were not encouraged to integrate into the Estonian society but, on the contrary, to be used as a vehicle for turning the Estonians towards the homo sovieticus model (Kultalahti et al. 1997, 68, 76-77; Kirch 1995, 15). The massive Russian immigration resulted in a strong Russification of political life, the activities of the Communist Party, the government and the economy as well as the cultural and educational systems. Thus, during Soviet occupation of Estonia a threat of a thorough organised assimilation of the Estonian nationality did exist. Indeed, the Estonian language, culture, and traditions vanished from the northeastern region of Estonia, and Tallinn has become a city inhabited by a majority of Russians and other Slavs (Geistlinger 1995, 96-97).

The question of the development of the ethnic structure in Estonia is not easy. For example, valid data describing the postwar Stalinist era (1944-1953) does not exist. Estimates are made difficult by two processes which took place simultaneously. Large numbers of Estonians were forcibly deported from Estonia while many Russificated Estonians from other parts of the Soviet Union were moved to Estonia. The annexation of the eastern border regions to the Russian Soviet Federal Socialist Republic (RSFSR) in 1945 did not involve major deportations of population with Estonian origin, for these regions were mainly populated by ethnic Russians. Thus the proportion of ethnic Estonians became to exceed 90 percent of the population in Estonia, despite the wartime losses.

The massive immigration of non-Estonians in 1945-1950, needed to meet the increasing 
demand for labor caused by expanding industrialization, caused the proportion of Estonians to drop precipitously, and the decline continued in the early 1950s (Raun 1987, 182-183). In the 1950 s the Estonian share of the population remained fairly stable. The birth rate of the ethnic Estonians was relatively high and non-Estonian immigration was relatively low. In the 1960 s and 1970 s the decline of the proportion of the native population in the ESSR was steeper than in any other republic of the entire Soviet Union. The native birth rate fell, and Russian and Slavic immigration increased (Raun 1987, 204).

Soviet data on the ethnic composition of the population is available for the census years $1959,1970,1979$, and 1989. Table 1 describes the major groups in these years. Unfortunately the first population data, reliable by western standards, will not be available until after the next census in 1999 or 2000.

Table 1. The ethnic divisions in Estonia

$\begin{array}{lccccccc} & \text { Estonians } & \text { Russians } & \text { Ukrainians } & \text { Belo-Russians } & \text { Finns } & \text { Other } & \text { Total } \\ \text { Year } & \% & \% & \% & \% & \% & \% & \text { N } \\ 1959 & 74.6 & 20.1 & 1.3 & 0.9 & 1.4 & 1.7 & 1,196,791 \\ 1970 & 68.2 & 24.7 & 2.1 & 1.4 & 1.4 & 2.3 & 1,356,079 \\ 1979 & 64.7 & 27.9 & 2.5 & 1.6 & 1.2 & 2.1 & 1,464,476 \\ 1989 & 61.5 & 30.3 & 3.1 & 1.8 & 1.1 & 2.2 & 1,565,662 \\ 1994^{*} & 63.9 & 29.0 & 2.7 & 1.6 & 1.0 & 1.9 & 1,506,927 \\ 1995^{*} & 64.2 & 28.7 & 2.7 & 1.6 & 1.0 & 1.8 & 1,491,583\end{array}$

Source: ESA 1996, 55

As shown in Table 1, the share of Estonians has increased in the 1990s and the share of nonEstonians has decreased. At the same time the population in Estonia has declined because of the mostly non-Estonian emigration in the time of transition, in the late 1980s and early 1990s. Another reason for the decrease are the low birth rates in 1990s. According to official statistics, in the mid-1990s the share of non-Estonians in Estonia was about 36 percent of the population. As mentioned above, the non-Estonian population is concentrated in the northern towns of Estonia, including the capital city of Tallinn. Thus, Estonian urban areas are of major importance when analyzing the differences among different ethnic groups.

\section{The data}

The data used in this article was collected in Tallinn (sample size ca. 920) and St. Petersburg (930) between April and September 1996. ${ }^{1}$ Altogether the data comprises 1,857 extensive questionnaires filled in by the employees of 171 enterprises and other organizations. The questionnaires were designed in cooperation with local partners from the Institute of Urban Studies, Tallinn, Estonia and Faxxon Ltd., Lappeenranta (Finland)/St. Petersburg, Russia. The partners also fitted the questionnaires to the cultural contexts of the case societies, and implemented the practical data collection.

For the following analyses respondents are classified into three groups: I) Estonians in Tallinn ( $\mathrm{N}=657)$, II) Russians, Belorussians and Ukrainians in Tallinn ( $\mathrm{N}=230)$, and III) Russians, Belorussians and Ukrainians in St. Petersburg $(\mathrm{N}=811)$. Moreover, 105 respondents represent other nationalities (see Table 2).

\footnotetext{
${ }^{1}$ The project on social changes and migration pressure in the transition economies of Estonia, Russia, the Czech Republic, and Slovakia by Kultalahti, Karppi, and Rantala.
} 
Table 2. Ethnic composition of the respondents in Tallinn and St. Petersburg

\begin{tabular}{lrrrr} 
& \multicolumn{2}{c}{ Tallinn } & \multicolumn{2}{c}{ St. Petersburg } \\
Nationality & $\mathbf{N}$ & $\%$ & $\mathbf{N}$ & $\%$ \\
Estonian & $\mathbf{6 5 7}$ & 71.3 & 0 & 0.0 \\
Russian, Belorussian & $\mathbf{2 3 0}$ & 25.0 & $\mathbf{8 1 1}$ & 92.0 \\
or Ukrainian & & & 71 & 8.0 \\
Other & 34 & 3.7 & 882 & 100.0 \\
Total & 921 & 100.0 & \multicolumn{2}{c}{ Missing values 54 }
\end{tabular}

The ethnic Russians in Tallinn are clearly underrepresented in the sample. This is due mainly to the following two reasons. Firstly, the sample was selected from the enterprise register to match the ownership types and size categories of Tallinn-based establishments. Thus, the sampling procedure was as randomized as possible. In Tallinn the organizations typically employ either Estonians or Russians. Due to the Tallinn enterprise structure the sample emphasized new small enterprises which typically employ Estonians - whereas the Tallinn Russians are typically employed by larger and older organizations. Second, the "Russian" enterprises were difficult to access due to a high rate of refusals. Further, the low rate of Russian respondents in Tallinn may be indicative of their lower labor market participation rate, or their activities outside the formal sector of the economy.

In fact, the coexistence of the formal and informal sectors was even more articulate in St. Petersburg. Even organizations which otherwise operate within the formal economy may em-

Table 3. Basic demographic and labor market-related indicators

\begin{tabular}{|c|c|c|c|}
\hline & $\begin{array}{c}\text { Tallinn } \\
\text { Estonians } \\
\%\end{array}$ & $\begin{array}{c}\text { Tallinn } \\
\text { Russians } \\
\%\end{array}$ & $\begin{array}{c}\text { St. Petersburg } \\
\text { Russians } \\
\%\end{array}$ \\
\hline \multicolumn{4}{|l|}{ Average age } \\
\hline Sex Years & 38.9 & 39.9 & 36.2 \\
\hline Male & 41.2 & 42.6 & 44.3 \\
\hline Female & 58.8 & 57.4 & 55.7 \\
\hline Total \% & 100.0 & 100.0 & 100.0 \\
\hline Total N & 657 & 230 & 805 \\
\hline \multicolumn{4}{|l|}{ Marital status } \\
\hline Single & 25.9 & 22.0 & 23.3 \\
\hline Cohabiting & 12.6 & 7.9 & 9.4 \\
\hline Married & 48.2 & 55.9 & 50.8 \\
\hline Widowed & 3.2 & 1.3 & 1.6 \\
\hline Divorced & 8.3 & 9.7 & 12.2 \\
\hline Separated & 1.8 & 3.1 & 2.6 \\
\hline Total \% & 100.0 & 100.0 & 100.0 \\
\hline Total N & 653 & 227 & 794 \\
\hline \multicolumn{4}{|l|}{ Average family size } \\
\hline Persons & 3.0 & 3.1 & 3.0 \\
\hline \multicolumn{4}{|l|}{ Education* } \\
\hline Nonacademic & 47.7 & 43.5 & 18.3 \\
\hline Academic & 52.3 & 56.5 & 81.7 \\
\hline Total \% & 100.0 & 100.0 & 100.0 \\
\hline Total N & 652 & 230 & 810 \\
\hline \multicolumn{4}{|c|}{ Average length of current tenure } \\
\hline Years & 6.6 & 10.2 & 6.4 \\
\hline
\end{tabular}


ploy part of their personnel "off the books". Normally everyone employed in the official labor market has second jobs which may not be included in the formal sector. From our St. Petersburg case we learned that it was specifically the white-collar workers and professionals who were officially employed by the organizations studied (see the biased distribution of the education levels in Table 3). On the other hand many organizations hire the blue-collar workers informally, so officially they do not even exist. Thus, many researchers studying industrial relations in Russia find it impossible to collect information from blue-collar workers in their workplaces.

Table 3 summarizes some basic features of the three respondent groups. While most of the figures can be taken as purely descriptive statistics, some aspects are worth a closer discussion. The average length of current tenure reflects the level the transformation has reached in the population groups in question. The shorter the average tenure the more thoroughly organizations have "recycled" their personnel. On the other hand it may be primarily a reflection of the larger number of recently established organizations within the reach of the population groups in question.

In Tallinn, the ethnic Estonians have worked for their current employer for a remarkably shorter period than the ethnic Russians. This suggests that Estonians work more frequently in the modern sector of the economy which emerged during the transition to a market economy. The ethnic Russians in Tallinn seem to have more often remained in the jobs they held during the Soviet era. The biased distribution of St. Petersburg respondents distorts their average length of tenure. In the 1990s their employing organizations seem especially to have recruited young managerial and professional staff, even if the older technocrats have kept their positions as well.

From the viewpoint of migration research the biases have some consequences. Among these factors are the age, sex, and education level of the respondents. Younger persons are more likely to migrate than older persons, men more likely than women, and the more educated more likely than the less educated. According to these parameters the St. Petersburg respondents should be those with the most potential to emigrate. However, as will be seen below, this obviously is not the case.

Another type of bias is due to the fact the data comprises active labor market participants. Thus the willingness to migrate as shown by the respondents cannot be generalized to the entire population. Instead, it is worth emphasizing that the aim of the study was to analyze factors and processes that affect the migratory decisions of the labor force. This fact must be taken into account when estimating the potential migration flows based on the current findings.

\section{Factors reflecting relative deprivation among the studied groups}

Factors related to emigration of the different ethnic groups may be linked to relative deprivation. In all post-socialist transition economies relative deprivation is now extremely acute. In terms of political liberalization and seizing the opportunities for prospering, the transition process has been that of advancement. However, its side effect has been a dramatic widening of income differences during the 1990s as well as an absolute increase in poverty (Niggle 1997, 58, SUSR 1995). Thus, more and more people have found the improvement of their personal well-being lagging behind overall development - or even deteriorating from what they had reached by the end of the 1980 s and the socialist era.

The seeds of relative deprivation have thus been sown. Runciman $(1966,10)$ arranges the steps of what can be called a "deprivation process". His model can be further streamlined into a game where person $A$ becomes relatively deprived of utility $X$ when:

- $1 \mathrm{~s} /$ he does not have $X$

- 2 s/he sees other persons or himself in some previous time space as having $X$

$\cdot 3$ s/he wants $X$

- 4 it is within his/her reach to achieve $X$.

The model thus suggests that in order to feel relatively deprived one should be able to change the circumstances which caused the state of deprivation. When improvement is not 
within sight, and resources needed for improvement cannot be collected, a person is expected to remain in a state of apathy instead of acting for change.

These dynamics were one of the main messages given by Davies (1962) when he presented the framework for a process theory of revolution. Prolonged improvement in living conditions and the rising expectations this leads to, followed by a sharp and sudden reversal without an equally quick hope for the better creates favorable ground for violent disturbances. Even if this is how deprivation may or may not escalate in the longer run, various groups constantly set their own short-term expectations, thus causing endless systemic oscillation in the aggregate need satisfaction in a given society (cf. Gurr 1971, 298). Furthermore, in the transition economies especially the time span set for expected improvement and prospering - to reach the Western living standards as quickly as possible - is emphatically short.

The concept of relative deprivation usually refers to relations between different segments and strata of the society, within one ethnically and territorially definite reference group. Differing to a certain extent from this approach, in our analysis deprivation becomes acute or exposes itself as differences between the living conditions of the population groups studied. What especially catches one's attention is the position of the ethnic Russian minority in Estonia - a position which has also caused some unrest in the relations between Estonia and Western integration organizations (cf. Kultalahti et al. 1997, 77, 80). From the viewpoint of ethnically based deprivation, the most obvious comparison in our data takes place between the Russian and Estonian respondents in Tallinn. On the other hand, for the Tallinn Russians who experienced the fast and profound transition process in Estonia, the Russians living in Russia as well as in other successor states of the former Soviet Union constitute a far more distant and abstract reference group.

Transition economies differ from the Western liberal democracies with regard to the "normally" functioning institutions of a market economy and sociological explanations based on

Table 4. Countries of destination for the most recent holidays and work trips

A) Destination of the most recent holiday

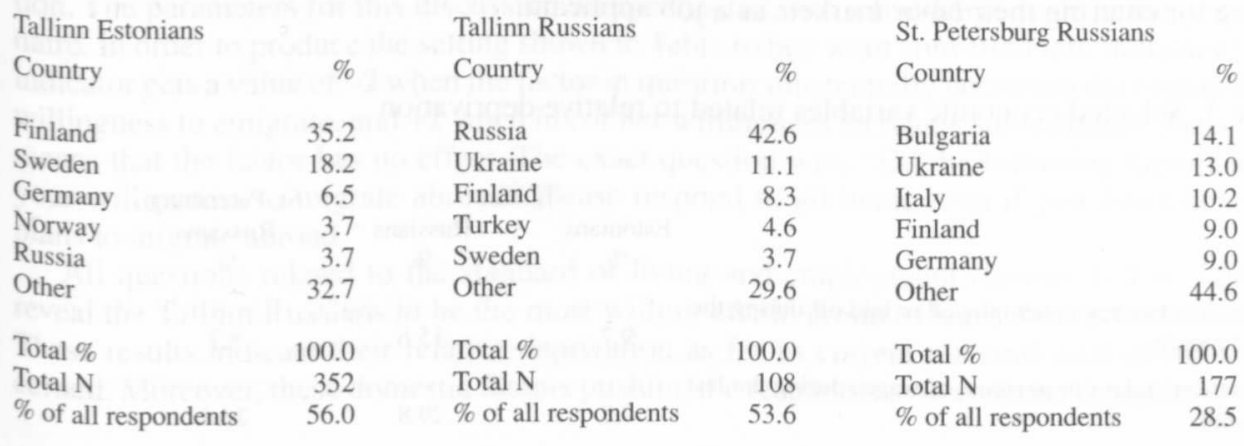

B) Destination of the most recent work trip

\begin{tabular}{lrlrlr} 
Tallinn Estonians & & Tallinn Russians & \multicolumn{2}{l}{ St. Petersburg Russians } \\
Country & $\%$ & Country & $\%$ & Country & $\%$ \\
& & & & & 29.3 \\
Finland & 44.9 & Russia & 42.4 & Finland & 15.2 \\
Sweden & 12.1 & Sweden & 15.2 & Germany & 8.7 \\
Germany & 10.6 & Finland & 12.1 & Sweden & 5.4 \\
Denmark & 3.9 & Germany & 9.1 & Estonia & 5.4 \\
Lithuania & 3.4 & Great Britain & 6.1 & Ukraine & 35.9 \\
Other & 25.1 & Other & 15.2 & Other & 100.0 \\
Total $\%$ & 100.0 & Total \% & 100.0 & Total \% & 92 \\
Total N & 207 & Total N & 33 & Total N & 15.1 \\
\% of all respondents & 32.9 & \% of all respondents & 16.8 & \% of all respondents
\end{tabular}


them. Particularly in the countries which have arisen with the disintegration of the former federal states (USSR, Czechoslovakia, Yugoslavia), nationalist sentiments frequently replace the rationality of homo economicus the relative deprivation model also counts on. Even if it may not be correct to refer to present-day witch hunts, national minorities, especially are sometimes accused of having negative attitudes towards the ongoing development, and of being obstacles to modernization and transformation to market economy. To a certain extent this is the case with some Estonian attitudes towards the Russian minority, sometimes for an obvious reason (cf. Vöörman 1993, 32).

In the context of this text, migration is seen as a possible response to relative deprivation. By saying this we expect that migrants can improve their relative rank status in relation to their reference groups. However, in order to set more proper expectations concerning this improvement, a migrant should be able to gather information from the possible countries of destination. Because of this, the countries or cultural spheres where the respondents prefer to travel may indicate their future orientations as more permanent settlers. Means for gathering information vary from holiday trips to more permanent sojourns abroad. Table 4 describes these country orientations among the ethnic groups studied.

The figures in Table 4 show how overwhelmingly the Nordic countries and Germany attract Tallinn Estonians for both holiday and work trips. If we wish to find some implications for their future migratory decisions, it is obvious that both geographical and cultural proximity are key factors here. On the other hand the orientations of the Tallinn Russians seem to suggest a more articulate inclusion in Russia.

Work-related trips are very specific sources of information. The same applies to studies completed abroad. Other important sources are social networks such as relatives or friends living in other countries. Our findings reveal that the relatives of the ethnic groups studied are concentrated in different regions. The Estonians can be found in North America and Scandinavia whereas the Ethnic Russians in Estonia have relatives especially in the territory of the former USSR. Among the Tallinn Estonians with the ability to understand Finnish, TV broadcasts from Finland are still of great importance in acquiring information. If relative deprivation is caused by one's position in the labor market, one seeks to gather information especially concerning the demand for workforce in the desired countries of destination, and the optimal timing for entering their labor markets as a job applicant.

Table 5. Selected economic variables related to relative deprivation

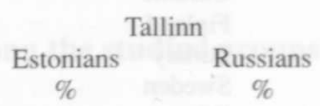

9.7

9.8

12 months

Expected severe economic difficulties due to a 3-month unemployment

Economic development of home country during the last 12 months

Good

Not good

Economic situation of one's family during the last 12 months

Good

Not good

Economic development of home country within the next 2 years

\section{Good}

Not good

Economic situation of one's family within the next 2 years
Good $\quad 40.9$

Not good $\quad 20.9$

\author{
St. Petersburg \\ Russians \\ $\%$
}

8.7

26.4

55.4

20.0

57.2

21.9

40.5

34.2

34.4

34.6

27.6 
The most efficient way to gain entry into the international labor market is to find employment in a local subsidiary of a foreign-owned corporation with its interorganizational linkages and possible human resource development programs. These channels do away with most obstacles to international migration, but they are available only to the highly qualified personnel the corporation values as its strategic resource. The Estonians in Tallinn seem to have moved into organizations which send their personnel mostly to West European countries, whereas the Tallinn Russians have obviously remained more often in the organizations with traditional ties and work trips heading for Russia (cf. Table 4B).

All three groups differ from each other in regard to many other economic as well as noneconomic factors. Some of the economic factors are illustrated in Table 5. The numbers representing Tallinn labor markets suggest some structurally induced ethnic segmentation. Organizations which employ mostly Russians seem to leave their employees in a more insecure position both in terms of job security and monetary compensation. This is reflected also by the experienced as well as expected changes in the incomes of respondents' families, with the Tallinn Russians being the most pessimistic group.

The Tallinn Russians can be regarded as being deprived of some of the steps of advancement the transition has brought to the ethnic Estonians. At least the details illustrated in Table 5 taken as a whole suggest that the hardships it caused tend to accumulate most often among the Russian respondents in Tallinn. Moreover, this group tends to be remarkably pessimistic concerning its expectations for the future when compared with past assessed developments. In these respects the Tallinn Russians indeed indicate fairly good reasons for considering emigration as a means of enhancing their well-being.

\section{Towards the analysis of propensity to emigrate}

In the following we develop the argument that the willingness to emigrate among different population groups reflects the differences in their socioeconomic security. We will especially study whether the ethnic Russians in Tallinn seek to improve their conditions through migration. The parameters for this discussion were collected with a five-stage scale in the questionnaire. In order to produce the setting shown in Table 6 they were converted into indicators. The indicator gets a value of -2 when the factor in question substantially decreases the respondent's willingness to emigrate, and +2 when his or her willingness increases substantially. Zero value means that the factor has no effect. The exact question was: "Do the following factors affect your willingness to migrate abroad? Please respond to all items even if you don't have any plans to migrate abroad."

All questions related to the standard of living and employment (factors 1-4 in Table 6) reveal the Tallinn Russians to be the most willing ethnic group to leave their present country. These results indicate their relative deprivation as far as current material well-being is concerned. Moreover, these domestic factors pushing the respondents to consider emigration obvi-

Table 6. Mean values of selected factors related to respondents' willingness to emigrate by ethnic groups (see text)

Push and pull factors

(cf. Figures 1 and 2)

1. Improved standard of living

2. Present wage/salary

3. Competition in current workplace

4. Changing or seeking a job

5. Graduation or break of studies

6. Commencing of studies

7. Crime in home country

8. Family members abroad

9. Xenophobia abroad

Estonians
0.87
0.44
0.25
0.38
0.02
0.64
0.40
0.73
-0.47

Tallinn

Russians
0.98
0.71
0.31
0.85
0.19
0.46
0.40
0.32
0.01

St. Petersburg
Russians
0.74
0.59
0.09
0.46
0.09
0.22
0.45
0.07
-0.17


ously correlate with an insecure position in terms of employment security and monetary income (cf. Table 5).

There are also factors related to the situation in the possible countries of destination. They are most often connected to the migrant's self-assessed ability to integrate into the new environment with regard to social networks or personal labor market value. This is the case especially among the Tallinn Estonians: for them family ties abroad and commencing studies combined with the aim of improving their standard of living constitute a pattern clearly differentiating them from the two reference groups. This indicates that the Estonians are more goalorientated in their international migratory decisions: they seem to emigrate in order to achieve something for which migration is a means.

This is the obvious difference between the Tallinn Estonians and Russians. The figures for the Tallinn Russians allow an interpretation that for them considering international migration is a sign of a lack of opportunities for socioeconomic improvement in Estonia. This interpretation is further supported by the fact that for them xenophobia in the possible country of destination is to a far lesser extent an obstacle than for both Tallinn Estonians and Russians living in St. Petersburg. It may even be possible to maintain that the Tallinn Russians feel an atmosphere of ethnically based exclusion in the Estonian society. Thus, potential socioeconomic marginalization involved in emigration and landing in a new social environment does not represent such a risk to the Tallinn Russians as it does especially to the Estonians.

One of the most illustrating determinants of marginalized post-migratory status is a labor market position in a secondary sector as an unskilled worker. Traditionally, migrant groups have formed an important reserve of excess labor force. Especially for Estonians, but also for Russians in St. Petersburg, staying in their countries of origin reduces the risk of ending in this labor market segment. On the other hand, in Estonia the Russians already living there represent a certain "otherness" which is often attached to migrants with foreign ethnic backgrounds.

The ethnically-based differences are further illustrated in Figure 1. In it the factors standing for Tallinn Russians in Table 6 equal 100, and the curves representing the Tallinn Estonians and St. Petersburg Russians are proportional to them.

Figure 1. Standardized push and pull factors by ethnic groups

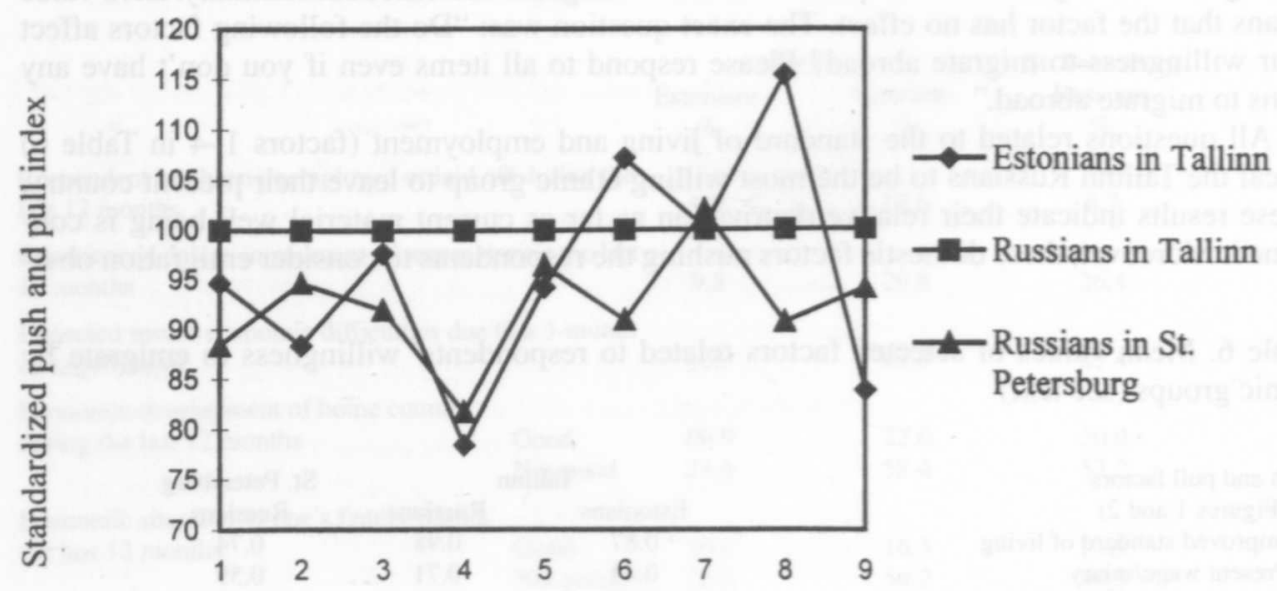

Push and pull factors (see Table 6) 
The first five factors, especially, show a clear similarity between the two national majority populations, the Tallinn Estonians and the St. Petersburg Russians, in relation to the Russians in Tallinn. These factors refer to economic aspects in general and labor market positions in particular. If we regard the Tallinn Russians as a group with a remarkably high basic propensity to emigrate due to their unfavorable position in the Estonian labor market, we can indicate factors that are especially relevant in reducing the majority groups' pressures to emigrate (push/pull index $<100$ ), or that may be their specific triggers of emigration (push/pull index $>100$ ). Factor 4 (changing or seeking a job) clearly appears to keep the members of both ethnic majority groups from emigrating. This coincides with the variation in length of current tenure (cf. Table 5 ), suggesting that the domestic labor markets operate more efficiently for the members of the ethnic majorities than for the other ethnic groups.

In many cases one could be easily tempted to assume that the Russians in Tallinn share properties of their two reference groups, either on the bases of ethnicity (Russian) or socioeconomic environment (Estonian society). However, this is the case in few and inconsistent instances such as factors 6 (commencing studies) and 8 (family members abroad). On the other hand, in rare cases such as factor 7 (crime in home country) the profiles for all ethnic groups converge. All three ethnic groups seem to regard crime in the home country as a factor that triggers rather than hinders the emigratory decision. This is the case especially in St. Petersburg (cf. Table 6).

However interesting these indicators and profiles are, they tell very little about the actual decision to emigrate. They are only background factors whose cumulative effect may result in a person's leaving the country. This cumulation is captured in the migration propensity index (Table 7). This index is constructed from three distinct and independent questions and based on the Guttman scaling technique (Neuman 1994, 161-163). The value of the index ranges from zero to three. The respondents with the highest expected propensity to emigrate (group III) have three properties: 1) they have considered the possibility of working abroad, 2) they would in case of unemployment try to find a new job abroad and 3) they intend in the near future to migrate abroad for more than one year. The respondents in group II share properties 1 and 2 and respondents in group I property 1 . The respondents in group 0 have never even thought of the possibility of working abroad. The cumulation refers to a structure where the lower order property is a necessary precondition for the higher.

Table 7. Propensity to emigrate by ethnic groups

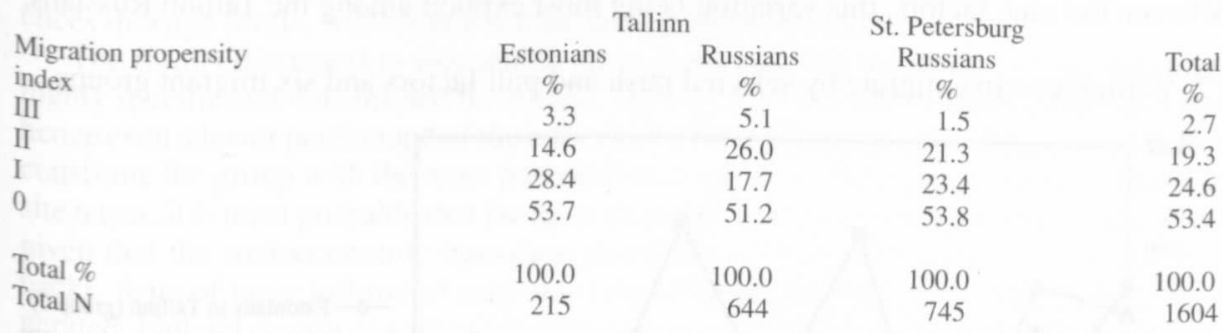

Missing values $=148$

The percentages in Table 7 confirm the previously discussed findings that the Tallinn Russians are the group most willing to emigrate. They are, moreover, the most serious about their plans. Building on the indicators in Tables 5 and 6 and in Figure 1, this willingness can be explained with their explicit aim to enhance their economic conditions, to emigrate in order to seek a job abroad. But where might they go? Table 8 shows the most favored countries of destination for the respondent groups in regard to work and staying a longer time or permanently. The resemblance between these countries and the destinations of the respondents' recent work trips shown in Table 4B is obvious.

The lower emigration threshold for the Tallinn Russians can also be seen in Table 8 in the share of respondents able to specify a particular country as a probable destination for their 
Table 8. Most favored countries of permanent residence by ethnic groups

\begin{tabular}{lrlrlr} 
Tallinn Estonians & & Tallinn Russians & & St. Petersburg Russians \\
Country & $\%$ & Country & $\%$ & Country & $\%$ \\
Finland & 29.5 & Germany & 20.8 & USA & 23.0 \\
Sweden & 11.4 & Finland & 14.6 & Germany & 16.0 \\
USA & 11.4 & Russia & 14.6 & Great Britain & 11.0 \\
Germany & 8.6 & USA & 10.4 & Finland & 8.0 \\
Other & 39.1 & Other & 39.6 & Other & 42.0 \\
Total \% & 100.0 & Total \% & 100.0 & Total \% & 100.0 \\
Total N & 105 & Total N & \multirow{2}{*}{48} & Total N & 100 \\
$\%$ of all & & $\%$ of all & & $\%$ of all & 12.3 \\
respondents & 16.0 & respondents & 20.9 & respondents &
\end{tabular}

permanent residence. The most notable difference between the country lists in Tables 4B and 8 is the presence of the USA in the latter. This phenomenon can be explained by the respondents' rather numerous relatives and family members living on the North American continent. All in all, specific social or work-related contacts seem to affect the destinations preferred by the potential migrants. In the case of Tallinn Estonians and Russians geographical proximity, with the exception of the USA, gives the impression of a certain realism in these plans. On the other hand the St. Petersburg Russians tend more often to prefer large and globally important countries, more on a par with Russia as a large nation. St. Petersburg is a metropolis and thus metropolises of large countries are attractive to her inhabitants.

Figure 2 combines data from Tables 6 and 7. From it we see the variation between different migrant groups (cf. Table 7) with regard to nine push and pull factors (cf. table 6). For the sake of simplicity, only the two extreme migrant groups in each population studied are illustrated. The scale of the willingness indicator (y-axis in Figure 2) is the same as in Table 6, meaning that values below zero indicate decreasing willingness to emigrate whereas positive values indicate increasing willingness.

The general feature in Figure 2 is that practically all factors increase the propensity to emigrate more within the groups most willing to emigrate than within the groups with no intention to emigrate. This may sound self-evident, but the remark includes a very specific kind of information: the respondents with no outspoken intention to emigrate are highly determined with their orientation. This is reflected by a low factor-to-factor variation among the potential nonmigrants (group 0). Instead, the most potential migrants (group III) show remarkable variation between the nine factors, this variation being most explicit among the Tallinn Russians.

Figure 2. Willingness to emigrate by selected push and pull factors and six migrant groups

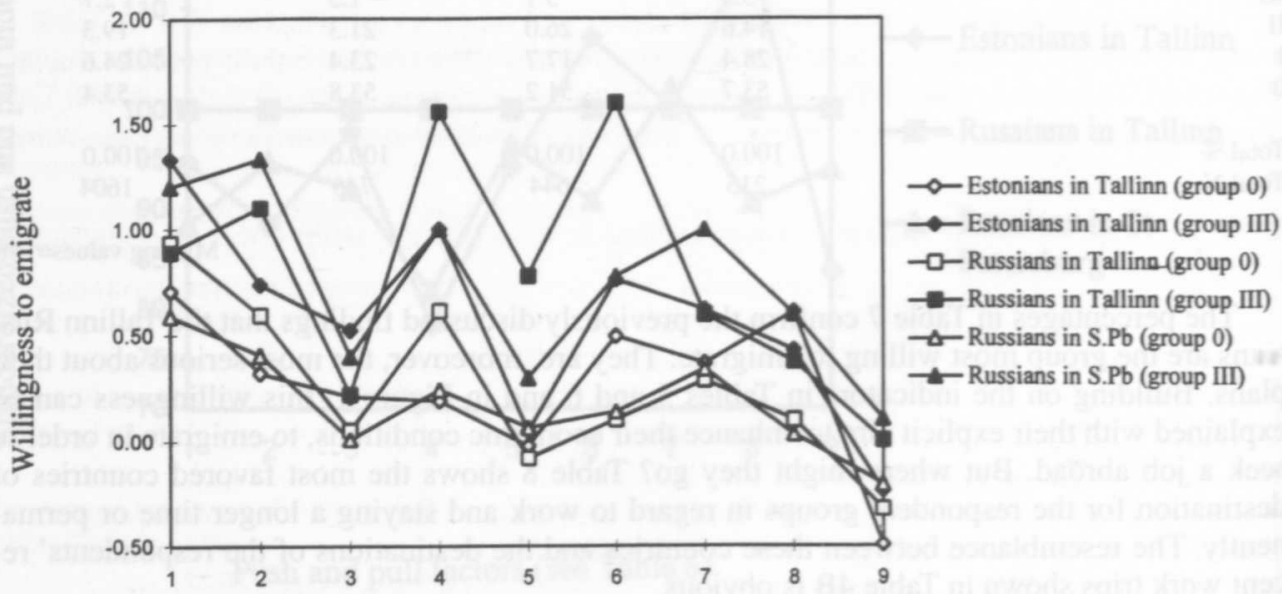

Push and pull factors (see Table 6) 
Figure 2 adjusts the image of Tallinn Russians as potential migrants. Previously we have postulated that they are less goal-orientated than the ethnic Estonians, in particular. However, in Tallinn there obviously exists a relatively small but yet clearly observable group of ethnic Russians who are extremely prone to leaving the country for foreign labor markets. This clearcut labor market orientation, indicated already in the preceding discussion, is highlighted by factor 4 (changing or seeking a job) in Figure 2. An interesting detail is that the positions of both the probably migrating (group III) and the probably nonmigrating (group 0) Russians in Tallinn, in relation to their two respective reference groups, is almost identical. Indeed, changing or seeking a job increases the willingness to emigrate among the potentially nonmigrating Russians in Tallinn far more often than among the two other potentially nonmigrating groups. However, for them improving the standard of living is the most important factor increasing their willingness to leave the country.

To sum up some of the previous discussions, it is obvious that many factors have an effect which increases basic willingness to emigrate in all ethnic groups studied. In fact, Figure 2 suggests that only a fear of xenophobia keeps the members of these groups from emigrating. Naturally this is not the entire picture because the distance from basic willingness to the concrete steps of migrating is long. The results discussed here give only a rough image of the processes behind the migratory decision. They feature the reasons that might trigger the migration and give an idea of which ethnic groups might be the most effected by changes in the situation underlying it. They also illustrate an economically insecure position and the resulting relative deprivation as a factor leading to an increasing propensity to emigrate. International migration still appears as a strategy for some particular groups to improve their material conditions.

\section{Implications for Finland and further research}

In the 1990s the number of Russians and Estonians in Finland, especially in the southern parts of the country, has increased due to the crumbling of the Iron Curtain. International labor markets in the Baltic Sea area are gradually starting to function normally, thus adjusting the supply of labor force to its demand. In other words the migratory movements in the area can be seen in the light of a more normal mobility of production factors (cf. Karppi 1997). This means that a notable east-west labor force movement in the area, caused by the transition and differences in wage levels, will remain a long-lasting phenomenon.

The results discussed in this article show, however, that the stock of potential migrants is highly specific and thus limited in volume. Only 1.5 to 5 percent of the populations studied and hence even a lower percentage of the entire labor force, depending on their ethnic backgrounds, constitute the group with the most potential to emigrate to the regions studied. Stated in opposite terms, it is most probable that far more than half of the respondents will not emigrate. Thus, given that the socioeconomic transition in the Baltic Sea area occurs without any major setbacks, fears of large inflows of migrants from Russia and Estonia to Finland have been exaggerated. Finland is seen as somewhat attractive among the ethnic Estonians in Tallinn, but even in this group a great number of respondents have a negative image of Finland as a potential country of destination. Among the Russians in Tallinn a negative image prevails, and the orientation towards Finland among the respondents in St. Petersburg can be described as neutral if not nonchalant.

What we just mentioned gives an idea that the ethnic group with the highest propensity to emigrate has the highest mental barrier to regarding Finland as its potential country of destination. On the other hand, one third of the ethnic Estonians with the highest propensity to emigrate indicate Finland as the country in which they have planned to work and stay a longer period of time. While those with the most potential to migrate constitute approximately 3 percent of the studied Estonian labor force in Tallinn, it can be estimated that ca. 1 percent of this population (one third of the three percent) has detailed plans to move to Finland. On the level of the entire ethnic Estonian labor markets in Tallinn and given the biases in the population stud- 
ied, it is possible to estimate that the most or highly potential foreign entrants to the Finnish labor market make up a stock of some 1,000-1,500 individuals. These figures are based on an assumption that the ethnic Estonian population in Tallinn is about 220,000 and that the labor force participation rate in Tallinn is as high as 55 percent (Venesaar 1995, 342).

One of the main ideas in this article has been that of relative deprivation. An interesting finding is that individuals in groups such as the ethnic Russians in Estonia, who obviously have suffered from the negative side effects of the transition more than ethnic Estonians, are not necessarily the only persons with a high potential to emigrate. Our finding has been that on the level of entire populations a higher income level and more equal distribution of income correlate with a basic willingness to emigrate. This, we have argued, speaks for a strong link between resources needed for migration and this willingness. The implication derived from the above is that there is no single model able to explain transition-related east-west migratory flows. The relationship between the willingness to emigrate and the basic economic indicators is not self-evident.

Prosperity in the nearby transition societies will create resources needed for goal-orientated migration which may increase the number of potential migrants, some of them finding Finland as their most-wanted country of destination. However, there are two sides to the coin. Deepening relative deprivation among some ethnic or social groups may boost discontent that in turn may accumulate into unexpectedly high propensities to emigrate. Instead of looking at a limited number of indicators illustrating the (macro) economic developments in the transition countries, more attention should be given to their internal dynamics regarding social processes such as deprivation, exclusion and movements between different social layers and strata.

\section{References}

Clement, Norris C. 1997. The changing economics of international borders and border regions. In: Borders and border regions in Europe and Northern America, edited by Paul Ganster, Alan Sweedler, James Scott, and Wolf-Dieter Eberwein, pp. 47-63. San Diego: San Diego State University Press.

Cohen, Robin. 1988. The new helots: migrants in the international division of labour. Aldershot: Gower.

Davies, James C. 1962. Toward a theory of revolution. American Sociological Review 27(1):5-19.

ESA (Eesti Statistikaamet). 1996. Statistical yearbook. Tallinn: Statistical Office of Estonia.

Geistlinger, Michael. 1995. The legal status of Russians in Estonia in the light of public international law. In: Estonia - a new framework for the Estonian majority and the Russian minority, edited by Michael Geistlinger and Aksel Kirch, pp. 93-120. Ethnos 45. Wien: Braumüller.

Gurr, Ted. 1971. A causal model for civil strife: a comparative analysis using new indices. In: When men revolt and why: a reader in political violence and revolution, edited by James C. Davies, pp. 293313. New York: The Free Press.

Karppi, J. Ilari. 1997. Labour force mobility in the Baltic Sea area and the transition economies: with special reference to economic integration. Forthcoming in: Yearbook of North European and Baltic Sea integration. Berlin: Springer Verlag.

Kirch, Aksel. 1995. Historical survey on the problem of the Russian minority in Estonia. In: Estonia - $a$ new framework for the Estonian majority and the Russian minority, edited by Michael Geistlinger and Aksel Kirch, pp. 8-18. Ethnos 45. Wien: Braumüller.

Kultalahti, Olli, J. Ilari Karppi, and Heikki Rantala. 1997. Baltic countries and the Baltic region. European spatial research and policy 4(1):63-83.

Neuman, W. Lawrence. 1994. Social research methods: qualitative and quantitative approaches. Boston: Allyn and Bacon.

Niggle, Christopher J. 1997. Income inequality in Central European transitional economies. In: Transition in Central and Eastern Europe, Vol I, edited by Zeljko Sevic and Glendal Wright, pp. 53-65. Belgrade: Yasf.

Raun, Toivo U. 1987. Estonia and the Estonians. Stanford: Hoover Institution Press.

Runblom, Harald, Mattias Tydén, and Helene Carlbäck-Isotalo. 1991. The Baltic region in history: the Baltic Sea Environment. Uppsala: Uppsala University.

Runciman, W. G. 1966. Relative deprivation and social justice: a study of attitudes to social inequality in twentieth-century England. Institute of Community Studies. London: Routledge \& Kegan Paul.

SUSR (Statisticky urad Slovenskej republiky). 1995. Social policy and social conditions: monitoring of the transformation to market economy in Slovakia in the 1989-1994 period. 314/95-7. Bratislava: Statistical Office of the Slovak Republic. 
Venesaar, Urve. 1995. Labour market. In: Transforming the Estonian Economy, edited by Olev Lugus and George A. Hachey, pp. 328-351. Tallinn: International Center for Economic Growth.

Vöörman, Rein. 1993. Are we ready for changes in society? EMI Courier 1/1993. Tallinn: Estonian Management Institute. 